\title{
Covid-19 - the impetus for public service innovation. Advancing the shift towards social procurement.
}

\author{
Natalia Spataru Lorenzo Cioni
}

\begin{abstract}
With the present and future being shaped by the Coronavirus disease and worldwide responses to it, critical insights are essential. The Covid-19 pandemic has profoundly influenced the lives of most people on the plane as well as the global market, some experts believing it has caused the worst economic decline since the Great Depression. The pandemic found States unprepared to face the challenges brought by it, it has exposed the vulnerabilities of individuals, societies and economies. A few months after the sparking of the first wave of Covid-19 it was possible to assess the earliest public intervention and to foresee how the virus is going to impact economic and social systems. Given the significant increase in public expenditure since the beginning of the pandemic, this Article will articulate and explore the role of public procurement in anticipating the risk of market failure, despite the complicated environment. Likewise, focus will be drawn upon the EU soft law instruments designed to respond to economic and public health issues, through the prism of solidarity. The Article will then focus on the analysis of the Italian response to the pandemic through public purchasing techniques.
\end{abstract}

\section{Keywords}

Public procurement; Covid-19 pandemic; Italy, European Union Commission; service innovation.

\section{Introduction}

With the present and future being shaped by the Coronavirus disease 2019 (Covid-19) pandemic and worldwide responses to it, critical insights are essential. The Covid-19 pandemic has profoundly influenced the lives of most people on the plane as well as the global market.

Millions of workers all over the world have been put on government-supported job retention schemes as parts of the economy, such as tourism or hospitality, came to a standstill under lockdown. Researchers predicted a $13.1 \%$ reduction in the EU gross domestic product (GDP) in 2020 and a fall in consumption and investment of $14.9 \%$ and $16.7 \%$, respectively. ${ }^{1}$

In August 2020, the International Monetary Fund (IMF) estimated that the global economy shrunk by $3 \%$, describing this decline as the worst since the Great Depression of the 1930 s. $^{2}$ Initial assessments indicate that as many as 40 million people may fall into extreme poverty, reversing a declining trend that lasted over two decades. Some 1.6 billion working in the informal sector could see their livelihoods at risk, and many lack access to any form of social protection. Numbers such as these are indicative of the immense risks of not acting swiftly, coherently, and in a

\footnotetext{
* The authors would like to thank Professor Roberto Caranta for his valuable expertise.

1 Commission, 'The Territorial Economic Impact of Covid-19 In the EU. A Rhomolo Analysis' $<$ https://ec.europa.eu/jrc/sites/jrcsh/files/jrc121261.pdf> accessed 15 October 2020.

${ }^{2}$ IMF, 'The Economic Effects of COVID-19 Containment Measures', WP/20/158
} 
coordinated manner. At the same time, they indicate the imperative to "build back better," in order to forestall similar risks to our future. ${ }^{34}$

The pandemic has exposed the vulnerabilities of individuals, societies and economies and has brought unparalleled challenges for governments to ensure not only the health of their citizens but also public service continuity, calling for a rethink of how economic and social activities are organised. It calls for strong responses based on solidarity, co-operation and responsibility and for a re-balancing of efficiency and resilience throughout the economy.

This study seeks to articulate and explore the role of procurement in anticipating the risk of market failure, despite the complicated business environment, and finding alternative solutions with relevant technical or demanding functions to the current economic situation. There will be analysed public procurement instruments of the European Commission (EC) and Italy - the first European nation to suffer heavily from the pandemic, at a stage of great uncertainty. Likewise, focus will be drawn upon service innovation during COVID-19 pandemic, as a novel phenomenon that contrasts with the common idea of service innovation as a primarily discretionary activity.

\section{European Union prospective}

The immediate reaction to COVID-19 in Europe was not exemplary. Critical medical health supplies were held in national warehouses while borders were closed, with a "my nation first" reaction, EC President Ursula von der Leyen described it. ${ }^{5}$ However, soon afterward, the European Union (EU) has reacted fast in time, by allocating the necessary resources and fund to mitigate the effects of the pandemic.

First, the European Central Bank launched a monetary package, worth $€ 750$ billion and later upgraded to $€ 1.35$ trillion, to counter the risks to liquidity and the outlook for the euro area. ${ }^{6} \mathrm{~A}$ massive pan-European crisis response package followed. The European Investment Bank and European Stability Mechanism (ESM) agreed to finance up to $€ 540$ billion to help people,

\footnotetext{
${ }^{3}$ UN Department of Economic and Social Affairs, Recovering better: economic and social challenges and opportunities, 11

<https://www.un.org/development/desa/en/wp-content/uploads/2020/07/RECOVER_BETTER_0722-1.pdf accessed 15 October 2020.
}

${ }^{4}$ Building Back Better (BBB) is a program that was first officially used in the United Nations' Sendai Framework for Disaster Risk Reduction, adopted on 3 June 2015 buy the UNGA. "The principle of 'Build Back Better' is generally understood to use the disaster as a trigger to create more resilient nations and societies than before. This was through the implementation of well-balanced disaster risk reduction measures, including physical restoration of infrastructure, revitalization of livelihood and economy/industry, and the restoration of local culture and environment".

5 Speech by President von der Leyen at the European Parliament Plenary on the European coordinated response to the COVID-19 outbreak, 26 March 2020,

$<$ https://ec.europa.eu/commission/presscorner/detail/en/speech_20_532> accessed October 2020.

6 European Central Bank announces ECB announces $€ 750$ billion Pandemic Emergency Purchase Programme (PEPP), 18 March 2020.

<https://www.ecb.europa.eu/press/pr/date/2020/html/ecb.pr200318_1 3949d6f266.en.html> accessed 15 October 2020. 
businesses and countries throughout Europe, including liquidity support to companies, funding for development of treatments and vaccines, and financing for employment as well as direct and indirect healthcare costs related to the pandemic.

Public procurement is a sensitive field in terms of the internal market's integrity. This is particularly so, when goods and services are swiftly needed to face the magnitude of a pandemic crisis as the one Europe is facing. The EC's soft law choice to address public procurement in emergency situations provides an interesting example to study. The soft law tools used by the EC show its commitment to provide support to the Member States in the public purchasing of protective equipment, medical goods and services, at a time when supply networks experience serious disruption, as in fact they did at the very outset of the pandemic outburst. The EC's intervention evolved along two different routes.

First, it has stepped up efforts by launching instruments under the Civil Protection Mechanism and joint procurement actions for various medical and similar goods. Since there are more than 250000 contracting authorities in the EU, the EC has declared its will to mobilize all available resources to provide further advice and assistance to Member States and public buyers. ${ }^{7}$

Second, in such harsh emergency situation, it was essential to prevent undesired delays for national authorities engaged in ensuring basic objectives, while following the EU legal framework. In this scenario, the EC has adopted a Guidance ${ }^{8}$ on the smart use of public procurement law during the COVID-19 crisis. Being aware of the imperative need of swift solutions to deal with an abrupt increase of demand for protective and other medical goods and services, the EC highlighted all the available possible options under the EU procurement framework. ${ }^{9}$ Thus, it has offered the national public authorities the possibility of substantially reducing the deadlines to accelerate open and restricted procedures, or even choose a negotiated procedure without publication - a solution that in fact entails a straight award, so as that a public authority is empowered to engage directly with the market.

\subsection{EU Civil Protection Mechanism (rescEU) and Joint Procurement Agreements}

In 2019, the EU reinforced and strengthened components of its disaster risk management by upgrading the EU Civil Protection Mechanism. The latest element introduced - rescEU stockpile ${ }^{10}$ - has the objective of enhancing both the protection of citizens from disasters and the management of emerging risks.

\footnotetext{
${ }^{7} \mathrm{R}$ Baratta, 'EU Soft Law Instruments as a Tool to Tackle the COVID-19 Crisis: Looking at the "Guidance" on Public Procurement Through the Prism of Solidarity' (2020) 5 European Papers 365.

${ }^{8}$ Commission, 'Guidance on using the public procurement framework in the emergency situation related to the COVID-19 crisis' (Communication) COM (2020) C108/01.

${ }^{9}$ Ibid.

10 The European Civil Protection Mechanism aims to strengthen cooperation between the EU Member States and participating States in the field of civil protection, with a view to improving the prevention, preparedness and response to disasters. See Commission, 'Strengthening EU Disaster Management: rescEU Solidarity with Responsibility' COM (2017) 773 final; Press Release (EC), 'COVID-19: Commission creates first ever rescEU stockpile of medical equipment' (19 March 2020)
} 
Under rescEU, the EC is planning a European stockpiling of medical countermeasures aimed at combatting serious cross-border threats to health. It will include: vaccines or therapeutics, intensive care medical equipment, personal protective equipment, laboratory supplies. The instrument receives $100 \%$ financing from the EC. ${ }^{11}$ The rescEU stockpile supplies for now include over 65 million medical masks and 15 million FFP2 and FFP3 mask; over 280 million pairs of medical gloves; almost 20 million medical gowns and aprons; several thousand oxygen concentrators and ventilators. The hosting States are responsible for procuring the equipment with the support of the EC. In early April 2020, European Medical Teams composed of doctors and nurses from Romania and Norway were deployed to Italy via the EU Civil Protection Mechanism and coordinated by the EU Emergency Response Coordination Centre. ${ }^{12}$ The Emergency Response Coordination Centre also managed the distribution of the equipment to ensure assistance to Italy - the first EU Member States hit by Covid-19. So far, 142,000 FFP2 and FFP3 protective facemasks from the rescEU medical reserve were delivered to Italy.

Within the framework of a coordinated EU health response, along with the rescEU, the Joint Procurement Agreement (JPA) has emerged as a core instrument to support a pan-European purchasing of personal protective equipment (PPE), ventilators and devices necessary for coronavirus testing.

One of the main characteristics of the JPA is its transparent nature: ${ }^{13}$ calls for competition notices are freely and openly advertised on the Official Journal; interested economic operators are provided with sufficient information in the call for competition notices to assess whether it is appropriate to tender for the contract: ${ }^{14}$ selection, evaluation criteria and the award procedure are made fully available to interested companies; $;{ }^{15}$ and, at the end of the competitive process, a contract award notice is published in the Official Journal. ${ }^{16}$ Additional information on the type of contract, costs is published on the EC's official website.

Under the JPA, Member States have the possibility of purchasing personal protective equipment, respiratory ventilators and items necessary for coronavirus testing. The co-ordination role belongs to the EC, while Member States purchase the goods. Since February 2020, the EC launched six procurement competitions to purchase medical supplies and equipment. Two procurement competitions related to PPE were conducted in February and March. The first one did not lead to

11 European Commission, Q\&A on the activation of the Emergency Support Instrument in the context of COVID-19 Pandemic - DG ECHO (December 2020), 3.

12 Commission, 'Crisis management and solidarity'<https://ec.europa.eu/info/live-work-travel-eu/coronavirusresponse/crisis-management-and-solidarity_en> accessed 21 January 2021.

13 The Directive 2014/24/EU of the European Parliament and of the Council of 26 February 2014 on public procurement and repealing Directive 2004/18/EC [2014] OJ L94/65 (2014 Procurement Directive) similarly requires contracting authorities to comply with the TFEU principles of transparency, equal treatment, nondiscrimination and proportionality.

${ }^{14}$ Joint Procurement Agreement to Procure Common Auction Platforms [9 November 2011] (JPA), Article 19.

15 JPA, Article 18.

16 Ibid. 
the awarding of a contract. ${ }^{17}$ The second tendering attempt was, by contrast, successful, and a framework agreement was awarded in March with an estimated budget ceiling of $€ 97$ million. ${ }^{18}$

The EC launched four different calls for tender for medical equipment and supplies: gloves and coveralls; personal protective equipment for eye and respiratory protection; ventilators; laboratory equipment. The national budget of Member States takes part in the JPA procedure, being provided $€ 3.3$ billion. ${ }^{19}$ This coordinated approach gave Italy - one of the first states which benefited from the medical-equipment purchased through a JPA - a strong position when negotiating with the industry on availability and price of medical products. ${ }^{20}$ As to the Covid-19 vaccines, Italy is relying entirely on JPA, which is, by now, using the vaccine developed by Pfizer and BioNTech as the bloc waits for other vaccines to be approved by the European Medicines Agency. ${ }^{21}$

It has been essential for Italy to benefit from these EU instruments in the health sector in order to address the shortage of personal protective equipment, ventilators, and medicines and to implement emergency cross-border health cooperation. Increased cross-border voluntary collaboration in the procurement of health technologies enables sharing experience and strengthens bargaining power, mitigating overly high transaction costs by pooling skills and capacities and through joint negotiations. ${ }^{22}$ The COVID-19 pandemic has shown that those strengths have been appreciated by Italy, and there is a growing acceptance and use of centralised cross-border procurement in the health sector.

\subsection{EC's guidance}

The EC's Guidance intendment is not meant only to guide national authorities as to how to take advantage of the inherent flexibilities of EU public procurement law in emergency times. Throughout the Guidance the EC has also assumed, along with national authorities, its own share of responsibility to respond properly to the serious public health issues related to the COVID-19 crisis. In this respect, the importance of the Guidance is material and deserves a short contextualization.

\footnotetext{
17 Tenders Electronic Daily, contract award notice 2020/S 051-119976 (2020).

${ }^{18}$ Commission, 'Covid-19 Response - Public Health' < https://ec.europa.e/nf/ive-work-travel-e/ealt/oronavirusrespons/ublic-health_en> accessed 21 January 2021.

19 European Commission, Q\&A on the activation of the Emergency Support Instrument in the context of COVID-19 Pandemic - DG ECHO (December 2020).
}

20 Commission, 'COVID-19: Commission creates first ever rescEU stockpile of medical equipment' press release '19 March 2020 <https://ec.europa.eu/commission/presscorner/detail/en/ip_20_476> accessed 21 January 2021.

21 Reuters, 'Italy to invest in biotech ReiThera to support COVID-19 vaccine development' $<$ https://www.reuters.com/article/us-health-coronavirus-italy-reithera/italy-to-enter-capital-of-reithera-tosupport-covid-vaccine-development-idUSKBN29A17V?edition-redirect=in> accessed 21 January 2021.

${ }^{22}$ WHO Regional Office for Europe, 'How can voluntary cross-border collaboration in public procurement improve access to health technologies in Europe? (2016) $<$ https://www.euro.who.in/_dat/sset/df_fil/00/3199/B21.pdf> accessed 21 January 2021. 
According to the Guidance's wording, ${ }^{23}$ public buyers have several options they can consider:

- In cases of urgency they can avail themselves of possibilities to substantially reduce the deadlines to accelerate open or restricted procedures.

- Should those flexibilities not be sufficient, a negotiated procedure without publication can be envisaged. Eventually, even a direct award to a preselected economic operator could be allowed, provided the latter is the only one able to deliver the required supplies within the technical and time constraints imposed by the extreme urgency.

- Public buyers should also consider looking at alternative solutions and engaging with the market.

These provisions accord public authorities a "safe harbour" in times of a state urgency. Had such authorities decided to shorten an open procedure or to resort to the accelerated restricted one, it is guaranteed that the EC would not challenge their actions and will refrain from launching infringement procedures for violation of the urgency test as set forth in Articles 27(3) and 28 (6) of the 2014 Procurement Directive. ${ }^{24}$

Moreover, as noted above, the Guidance has also suggested an extra simplified approach for public procurement in times of pandemic crises, by enabling national authorities to directly award public contracts through a procurement procedure without prior publication. Indeed, the EC has accepted that COVID-19 embraces the standards of "state of extreme urgency".

The EC's Guidance provides the possibility to change the procurement process by supporting simplified and accelerated procurements and thus speeding the effectiveness of the national response to COVID-19. When this speed and flexibility is achieved by removing red-tape and encouraging collaborative co-design without sacrificing accountability or transparency, the end result is lower costs, greater flexibility, and greater freedom to focus on outcomes. ${ }^{25}$

The Guidance also provides for the possibility to contact potential contractors by phone, e-mail or in person to agree to an increase in production or the start or renewal of production. The emphasis on dialogue between supplier and client proved to be crucial and many partnerships have embraced this new way of communicating into business as usual. Stakeholders often suggest that more flexibility in procurement procedures is needed, and that in particular, contracting authorities should be allowed to negotiate the terms of the contract with potential bidders. ${ }^{26}$ Such a possibility could hence be implemented in the general EU public procurement legislation, on condition of compliance with the principles of non-discrimination and fair procedure.

The global Covid-19 pandemic proved to be the catalyst for accelerated digital transformation in procurement and can make valuable contributions in the following areas:

\footnotetext{
${ }^{23}$ Guidance on using the public procurement framework in the emergency situation related to the COVID-19 crisis, above fn 8.

242014 Procurement Directive.

${ }^{25}$ Baratta, above fn 7.

${ }^{26}$ Commission, 'Green paper on the modernisation of EU public procurement policy Towards a more efficient European Procurement Market' COM (2011) 15 final.
} 
- Harmonized experience and simpler change management with a consistent user interface across all solutions, including guided tours, embedded learning and a digital assistant

- Faster, more informed decision-making through instant access to embedded intelligence, including proactive alerts to support smart and secure buying

- Improved visibility and real-time reporting with end-to-end analytics

- Lower total cost of ownership and rapid return on investment through unified integration that eliminates the need for costly services and support. ${ }^{27}$

\section{The Italian perspective}

On 6 April 2020, a letter, signed by the German Ministers of Foreign Affairs and Finance, was published in different languages in the national newspapers of some Member States. It stated «We need a clear expression of European solidarity in the corona pandemic [...] $»^{28}$. The hoped-for expression of European solidarity came right after. Following tough negotiations between the Member States, the European institutions set the target of relaunching European economy. In order to reach this goal, they did not limit themselves to deploying new economic means and upgrading the existing ones, such as European Stability Mechanism (ESM) ${ }^{29}$ and Recovery Fund $^{30}$, but they clarified the will to 'set the Union firmly on the path to a sustainable and resilient recovery ${ }^{31}$.

By delivering this statement EU institutions renewed their commitment for a social oriented development ${ }^{32}$. The adoption of a political strategy towards a fairer allocation of resources is relied to the importance of public spending. Even before the spread of the coronavirus pandemic the amount of money spent by the Member States on the purchase of works, services, and supplies ${ }^{33}$ is enormous, suffice it to say that around 14\% of their GDP is normally used to finance such acquisition. In 2019, Italian contracting authorities awarded public contracts for a total value of

27 Supply Chain, 'Gartner Reveals the Results of the 2020 Supply Chain Top 25’ $<$ https://www.supplychaindigital.com/supply-chain-2/gartner-reveals-results-2020-supply-chain-top-25> accessed 20 October 2020.

28 'A response to the corona crisis in Europe based on solidarity' <www.auswaertiges-amt.de> accessed 7 October 2020 .

29 'Eurogroup Statement on the Pandemic Crisis Support' <www.consilium.europa.eu> accessed 9 October 2020 .

30 'Special European Council, 17-21 July 2020'<www.consilium.europa.eu> accessed 9 October 2020.

${ }^{31}$ European Council, 'Special meeting of the European Council - Conclusions' (2020) 10, 2.

32 The will to achieve a sustainable growth may be deduced also by European Commission, 'A Farm to Fork Strategy for a fair, healthy and environmentally-friendly food system' <https://eurlex.europa.eu/resource.html?uri=cellar:ea0f9f73-9ab2-11ea-9d2d-

01aa75ed71a1.0001.02/DOC_1\&format=PDF> accessed 9 October 2020.

33 According to the data set out in ec.europa.eu (accessed 24 September 2020), every year public authorities in the EU spend around $€ 2$ trillion per year on the purchase of services, works and supplies. 
$€ 169,9$ billion. The Region which spent the most was Lombardia (almost €31 billion), whereas Valle d'Aosta was the one that spent less (around $€ 374$ million) ${ }^{34}$.

This data is probably going to increase due to the countercyclical policies implemented by the EU institutions. In fact, as a response to the disease, the EU earmarked additional resources ${ }^{35}$. These projections, and the fact that public spending can be a huge lever for stimulating innovation, demonstrate that the coronavirus pandemic represents a unique opportunity for the Member States to accelerate social development. The easiest way for accelerating development is making smart purchases. The expression 'smart purchases' is used to define such acquisitions that can help reducing disparities and implementing environment-oriented policies. This part of the paper aims to review the latter public procurement reforms to identify, if possible, a trend line that may help to understand how the incoming resources are going to be used and how can they contribute to advancing social innovation.

Up until the end of last century, the social and environmental facet in public purchasing was not considered a priority. In fact, in 1998 the Communication entitled «Public procurement in the European Union» contained claims such as "the Commission reiterates that the object of public procurement remains essentially economic" ${ }^{36}$. However, in Italy, the third-generation directives ${ }^{37}$ generated the enactment of the National plan on Green Public Procurement and minimum environmental criteria were made fully mandatory ${ }^{38}$. In other words, nowadays contracting authorities cannot award public contracts to companies that do not fit environmental and social benchmarks. Moreover, growing attention has been reserved to improving the efficiency of resource use and to reducing the generation of waste. Italy did not limit itself to transpose EU Directives, such as Directive 2008/98/CE, but broadly implemented more socially oriented policies.

\footnotetext{
${ }^{34}$ Autorità Nazionale AntiCorruzione, 'Relazione annuale 2019' $<$ https://beta.anticorruzione.it/documents/67828/84752/Relazione+Annuale+2019.pdf/79d48a36-f393-a61c1882-0730d2c110ad?t=1593680773263> accessed 3 November 2020.

35 European Council, 'Special meeting of the European Council (17, 18, 19, 20 and 21 July 2020) - Conclusions' (EUCO 10/2020).

${ }^{36}$ Commission, 'Public procurement in the European Union' COM (1998) 143 final, 27.

${ }^{37}$ Recital 1 of Directive 2004/18/EC of the European Parliament and of the Council of 31 March 2004 on the coordination of procedures for the award of public works contracts, public supply contracts and public service contracts [2004] OJ L134/114 set the tone stating that 'This Directive is based on Court of Justice case-law, in particular case-law on award criteria, which clarifies the possibilities for the contracting authorities to meet the needs of the public concerned, including in the environmental and/or social area, provided that such criteria are linked to the subject-matter of the contract, do not confer an unrestricted freedom of choice on the contracting authority, are expressly mentioned and comply with the fundamental principles mentioned in recital 2'. In fact, only few years later EU role was considered a pattern cf. S Oberthur and C Roche Kelly, 'EU Leadership in International Climate Policy: Achievements and Challenges', The International Spectator (2008) 43.

38 S Colombari, 'Le considerazioni ambientali nell'aggiudicazione delle concessioni e degli appalti pubblici', Urbanistica e Appalti, (2019) 5.
} 
Unfortunately, whilst during the last decades, the overall policy climate became more and more oriented towards the creation of a circular economy ${ }^{39}$, Italy's approach towards public contracting has been characterized by a lack of long time planning. An emblematic case is the one concerning the implementing regulation of the Public procurement code. As the fourth-generation directives were transposed in the new Public procurement code ${ }^{40}$ (d. lgs. 50/2016), the lawmaker repealed the former implementing regulation. From that moment on the implementing rules were to be set by National Anti-Corruption Authority guidelines. After only three years from the approval of the new Code, law decree n. 32/2019 introduced a novelty which led to a partial return to the past. As a result, nowadays some issues are covered by the guidelines and some issues should be disciplined by the new implementing regulation, which has not been approved yet ${ }^{41}$.

\subsection{Emergency regulation}

The regulatory framework became even more complex during the peak of emergency. In fact, even though the Public procurement code provides for specific arrangements to shorten the purchasing procedure, further rules were added to speed up the purchase of medical devices ${ }^{42}$. Analyzing some instances demonstrates the assumption that derogating from the rules concerning procedures may have accelerated the purchasing process, but, in order to set Italy 'on the path to a sustainable and resilient growth, lawmakers should pursue digitalization and socially oriented policies instead of encouraging the contracting authorities to resort to shortened procedures.

Before the spread of the disease, art 3 of an ordinance of the Head of Civil Protection Department (Ordinanza del Capo Della Protezione Civile Ocdpc n. 6303 February 2020) introduced a series of derogations to the Public Procurement Code. According to the first studies on this case ${ }^{43}$, the circumstance that those derogations were not sanctioned by a law, which is the proper mean to waive conditions having force of law, discouraged the contracting authorities from using the shortened procedures provided for in Ocdpc n. 630. It is empirically proven that contracting authorities kept awarding contracts by means of the traditional procedures ${ }^{44}$.

\footnotetext{
${ }^{39}$ An emblematic case is the one regarding energy communities cf. E Ferrero, 'Le comunità energetiche: ritorno a un futuro sostenibile', Ambiente e sviluppo, 2020677.

40 L Pardi, 'The New Italian Public Procurement and Concessions Code', (2017) EPPPL 57-59; Id., 'Implementation of the New Directives on Procurements and Concessions in Italy: a Chance for Domestic Regulation Improvement', (2015) EPPPL 316-319; see also R De Nictolis, 'Il nuovo codice dei contratti pubblici', (2016) Urbanistica e appalti 503.

${ }^{41}$ I Cavallini M Orsetti, 'I reali effetti del c.d. "Sblocca cantieri" sulle Linee Guida ANAC: un'occasione mancata per il tramonto del sistema di soft-law', Azienditalia (2020) 496.

${ }^{42}$ I Gobbato, COVID-19 and derogations from the procurement code in Italy, in www.jdsupra.com (accessed 10 October 2020).

${ }^{43}$ A Ruffini 'Le procedure di gara ai tempi del coronavirus tra rallentamenti ed accelerazioni' Urbanistica e appalti (2020) 460.

${ }^{44}$ A Ruffini 'Le procedure di gara ai tempi del coronavirus tra rallentamenti ed accelerazioni' Urbanistica e appalti (2020) 463.
} 
In early March 2020, Article 34 law decree n. 9/2020 allowed the 'implementing bodies' to acquire personal protective equipment and medical devices without applying the public procurement code until the end of the emergency.

Subsequently, another ordinance of the Head of Civil Protection Department (Ocdpc n. 65525 March 2020) enabled the local authorities to purchase services and supplies without following the dispositions regarding open procedures, restricted procedures and the publicity of calls for competition. The sole condition required was that such acquisitions had to be useful 'to ensure the management of situations linked to the pandemic ${ }^{45}$. This clause is clearly undetermined.

Different provisions were approved to safeguard enterprises. The legislator allowed public authorities to carry out advanced payments under strict conditions. According to the latest version of Article $35 \mathrm{~d}$. lgs. 50/2016, the amount of the advance payments should be equal to $20 \%$ of the price and must be paid within 15 days from the beginning of the execution. However, Article 207 law n. 77/2020 enabled public administrations to increase this amount up to $30 \%$ of the price; this opportunity will be available for all the procedures whose call for competition will be published before 30 June 2021. This novelty was significant because it has made it possible to ensure to many social economy actors the access to cash flow. Indeed, most social economy actors did not have large cash reserves due to the structure of their financial mode ${ }^{46}$.

\subsection{Insights for the future}

As explained above, the first phase has been characterized by several interventions of administrative institutions aimed at accelerating the public procurement process and safeguarding enterprises. In Italy, the outcome of these interventions resulted in the creation of simplified procedures ${ }^{47}$. It is already possible to foresee which will be the pros and the cons in the event that these procedures will be applied even after the Covid-19 pandemic is over. Whereas the greatest part of the rules introduced in the first phase intended to waive the application of the Public procurement code, in order to harmonise the different regulations, a process of rationalisation would be necessary. Indeed, once that the simplified procedures will be in force, the access to public contracts would be easier, especially for actors such as SMEs and Women Owned Enterprises ${ }^{48}$ which would benefit in particular from the rules concerning advanced payments.

\footnotetext{
45 A Varlaro Sinisi 'L'impatto dell'emergenza Covid-19 sulle procedure e sull'esecuzione dei contratti pubblici' Urbanistica e appalti (2020) 317.

46 'Social economy and the COVID-19 crisis: current and future roles' in www.oecd.org/coronavirus/policyresponses/social-economy-and-the-covid-19-crisis-current-and-future-roles-f904b89f/\#endnotea0z2

${ }^{47}$ Still the emergency has brought with itself questionable legislative measures, such as the one regarding the possibility to award public contracts on the sole basis of a provisional anti-mafia policy until 31 December 2021 (see Article 3 law decree n. 76/2020). The contracts stipulated by applying this novelty contain a cancellation clause in the event that the anti-mafia definitive checks result in a formal prohibition to conclude agreements with public administrations. This rule may accelerate slightly the administrative procedure, but it will surely result in uncertainty and litigation.

${ }^{48}$ Cf. B Hoekman B K O Taş 'Procurement policy and SME participation in public purchasing' Small Business Economics (2020) https://doi.org/10.1007/s11187-020-00414-z and K Heinonen T Strandvik 'Reframing service
} 
After the first phase, additional arrangements were introduced. Among these is the Article 75 of the decree n. 18/2020 (converted into law 27/2020), which provides a change in the tone of the framework demonstrating the will to pursuit short term objectives. In order to facilitate smart working, this provision features the opportunity for contracting authorities to purchase electronic goods and services through negotiated procedures without prior publication. This opportunity will be available until 31 December 2020 .

Given that the EC has clarified that negotiated procedure without prior publication is a tool to use in cases of extreme urgency ${ }^{49}$, it is impossible to foresee whether Article 75 d.l. 18/2020 is going to have a great impact on the way public employees work. Still, it is important to point out that, after many uncoordinated interventions, a clear disposition tried to pave the way for a targeted use of resources.

Article 120 d.l. 18/2020 is in line with the same criterion. It allocates around $€ 80$ million to acquire digital devices destined to facilitate remote learning in educational institutions. The largest part of these funds is earmarked to facilitate underprivileged students' fruition of online classes.

Those rules aim to achieve the objective of digitalisation ${ }^{50}$ in an innovative way; they encourage contracting authorities to use simplified procedures and bind the same authorities to use funds in order to reach specific goals. However future provisions could use the same approach to reach more ambitious targets ${ }^{51}$, such as implementing circular economy ${ }^{52}$ and reducing social disparities, in compliance with the SDGs. This kind of regulation would be in line with the path undertaken with the approval of the National Plan on Green Public Procurement. Some regions already implemented local plans in order to confirm the institutional commitment for a greener economy ${ }^{53}$. Targeted interventions by the contracting authorities (which are bond to respect minimum environmental criteria ${ }^{54}$ ) could trigger an upturn of the economic cycle.

In conclusion, a conscious use of public spending could be more effective than structural reforms, although both are needed in Italy. Using the words of German Ministers of Foreign Affairs and

innovation: COVID-19 as a catalyst for imposed service innovation' Journal of Service Management $<$ https://www.emerald.com/insight/1757-5818.htm> accessed 7 October 2020.

${ }^{49}$ Guidance on using the public procurement framework in the emergency situation related to the COVID-19 crisis, above fn 8 .

${ }^{50}$ For an analysis of the steps towards digitalisation in Italy cf. F Notari, 'Il percorso della digitalizzazione nelle amministrazioni pubbliche: ambiti normativi mobili e nuovi modelli di governance', (2020) Giornale di diritto amministrativo 21.

51 Autorità Nazionale AntiCorruzione, 'Strategie e azioni per l'effettiva semplificazione e trasparenza nei contratti pubblici attraverso la completa digitalizzazione: le proposte dell'Autorità', in www.anticorruzione.it.

${ }^{52}$ Cf. www.acquistinretepa.it/opencms/opencms/programma_acquistiverdi.html

${ }^{53}$ Cf. Regione Lombardia, 'Piano di azione per gli appalti verdi' <www.ariaspa.it/wps/wcm/connect/e9dd2953d0fa-41d6-b733-f16b9b5c349b/Piano+di+Azione+-+GPP+maggio+2020.pdf?MOD=AJPERES\&CACHEID=ROOTWORKSPACE-e9dd2953-d0fa-41d6-b733f16b9b5c349b-nal6p5.> accessed 7 October 2020.

${ }^{54}$ L Cioni, 'T criteri ambientali minimi sono una causa di esclusione?' Giurisprudenza Italiana (2020) 2237. 
Finance, Europe needs 'quick and targeted relief ${ }^{55}$. Those are the reasons why, even though nowadays in Italy most political debates concern whether to use or not the ESM fund, it appears evident that 'the key question is not whether but how the state should put its balance sheet to good use $e^{56}$.

\section{Conclusions}

COVID-19 is an international health crisis that requires quick and intelligent solutions and cleverness in dealing with an expansion of demand for goods and services while certain supply chains are disrupted. Public buyers are at the cutting edge for most of these goods and services, as it is their responsibility to ensure the availability of personal protective equipment such as face masks and protective gloves, medical devices, notably ventilators, other medical supplies, but also hospital and IT infrastructure, to name only a few.

The pandemic has driven numerous changes to economic activities and the way EU and its Member States function, bringing the role of public procurement to the fore. Addressing these challenges has prompted EC to rethink how to better protect EU citizens and use public purchasing as a lever to drive social innovation initiatives. Even though the initial response to the to the pandemic crisis has been slow, at a certain point EC changed attitude and decided to stick to the general principle of solidarity that is a feature of the European integration construct. Considering the EU soft law measures and legislative initiatives adopted during the pandemic crisis, it emerges a principle that is taking on deeper and newer connotations based on the awareness of a common interest, showcasing its positive contributions to reinforcing mutual connection and interdependence of people.

Italy may be regarded as an emblematic case. This State was severely hit by COVID 19, but it is now moving in the right direction. It has simplified the purchasing procedures and has promoted a more socially oriented public spending. In the aftermath of the first wave, it has started a process which will leads to structural reforms. Although the crisis has distraught the lives of million Italians, it seems to have brought a brand-new approach to public procurement. It is evident that such an approach will have to be the basis for a long-time schedule that should have as an objective the simplification of the public contracts matter.

\footnotetext{
55 'A response to the corona crisis in Europe based on solidarity' <www.auswaertiges-amt.de> accessed 7 October 2020.

56 M Draghi, 'We face a war against coronavirus and must mobilise accordingly', Financial Times, 24 March $2020<$ www.ft.com> accessed 10 October 2020.
} 